\title{
Optimum Monochromatic Wavelengths for Solar Panel Testing and Conversion of Parameters to STC
}

\author{
R. Jayakrishnan and Dr. P. V. Shouri
}

\begin{abstract}
Solar panels are one of the simplest devices to produce electricity from the sun. Even though the efficiency with which it harnesses energy from the sun is very less, its affordability and ease of use makes it a strong competitor in the renewable energy filed. The laboratory testing apparatus for these solar panels still makes use of halogen lamps for testing purposes. These equipments are costly, requires much electricity and the life expectancy is very less. Light Emitting Diode (LED) solar simulators are considered as the future of solar simulators due to their low cost and robustness. This work presents the various performance based experiments, viz., wavelength based, time based and irradiance based conducted on monocrystalline solar panels using LEDs of different wavelengths. The paper proposes suitable wavelengths for the testing purposes of solar panels in the light of obtained results. The mathematical conversion of electrical parameters like short circuit current and open circuit voltage to Standard Test Conditions (STC) are also done in this work.
\end{abstract}

Keywords--- Light Emitting Diode, Monocrystalline, Solar Panels, Solar Simulators, Standard Test Conditions, Temperature Corrections

\section{INTRODUCTION}

$\mathrm{M}$ ANY authors have investigated solar cell efficiency of grid connected PV systems under one sun intensity. The experiments were conducted on monocrystalline, multicrystalline and thin film solar panels by using natural sunlight and simulated lights. Even though researches in this area started decades ago, till date the researches combining solar simulator and solar panel are very few [1-13]. Researchers Shogo Kohraku and Kosuke Kurokawa for the first time used LED lights to measure the spectral response characteristics of solar cells [14]. The simplicity and low capital cost of the LED solar simulators favored further research into LED simulators. The Xenon and Halogen solar simulators consumed a lot of power and had shorter life period. These lamps provided satisfactory performance but the current consumption and shorter life periods were considerably disadvantageous for long term experimentations. Later they went a step further from their previous research and developed an LED solar simulator in their laboratory and

R. Jayakrishnan, Department of Mechanical Engineering, Model Engineering College, Cochin, India. E-mail: jnr.nair@gmail.com

Dr. P. V. Shouri, Department of Mechanical Engineering, Model Engineering College, Cochin, India. E-mail: pvshouri@gmail.com measured the characteristics of silicon solar cells with it [15]. The LED solar simulator was developed for a $100 \times 100 \mathrm{~mm}^{2}$ solar cell with colors of blue, red, infrared and white. The total area of illumination was $205 \times 205 \mathrm{~mm}^{2}$ from a height of $84 \mathrm{~mm}$. They measured the spectral response and I-V characteristics of solar cells in the range of $10 \mathrm{~mW} / \mathrm{cm}^{2}$. Their experiment proved that even a low intensity light like LED can estimate the I-V characteristics under AM $1.5 \mathrm{G}$ spectrum. They continued their experiment by comparing the obtained I-V curve values with that of a Xenon solar simulator [17]. While the earlier experiments were conducted in a continuous light mode, Grischke et al. performed flash mode on solar panel using LED Flasher arrays (LFA) [16].

Results were improved in array area and test plane area in subsequent experiments including all the available LED simulation modes i.e., continuous, flash and pulse [18-22]. Our experiment focused on two monocrystalline solar panels, a small test solar panel of $0.18 \mathrm{~W}$ and a commercially used 20W solar panel. The array for test solar panel was $6.5 \times 2.5 \mathrm{~cm}$ from a height of $1 \mathrm{~cm}$ and for larger solar panel it was $55 \times 35$ $\mathrm{cm}$ from a height of $15 \mathrm{~cm}$. Several factors affect the efficiency of solar cells [23]. But these effects were less predominant in our experiment. The cell temperature didn't rise up above $25^{\circ} \mathrm{C}$, Tracking methods weren't needed, and the cell was already coated with antireflective coating to minimize reflection losses. But as our experiment was conducted in non STC conditions, the values were to be converted to STC conditions using IEC correction methods [24].

\section{EXPERIMENTATION}

A small test solar panel of $0.18 \mathrm{~W}$ with dimensions $65 \mathrm{~mm} \times 40 \mathrm{~mm}$ and a commercial 20W solar panel of dimensions $55 \mathrm{~cm} \times 35 \mathrm{~mm}$ were analyzed in the study. The LED flood light was illuminated in such a way that it clearly covers the length and breadth of the solar panels in separate experiments.

The experimental setup is shown in Fig. 1. The multimeter is connected directly to the positive and negative ends of the small solar panel. A 10 watt LED Flood light capable of producing 15 different colors of light is placed just above the test solar panel. The distance between Light source and solar panel is $10 \mathrm{~mm}$ for small $0.18 \mathrm{~W}$ solar panel and $15 \mathrm{~cm}$ for $20 \mathrm{~W}$ solar panel. After conducting experiments with test solar panel, it is removed from the setup and replaced with the commercial solar panel. The distance between light source and solar panel are adjusted accordingly. 


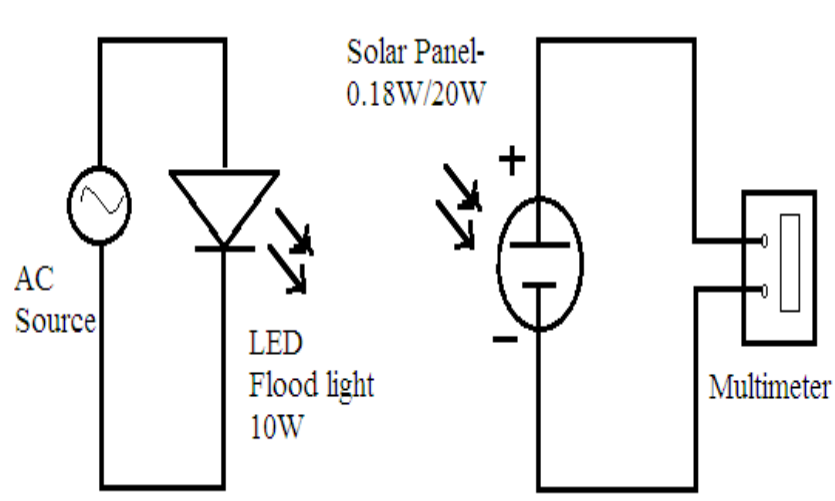

Fig. 1: Schematic Representation of Experimental Arrangement

When light falls on the test solar panel, it produces a current and voltage which is measured and noted down. Measurements using multimeter are made by touching the black lead (COM lead) of multimeter to the negative end and the red lead (V $\Omega \mathrm{mA}$ lead) to the positive end of the solar panel.

The wavelength based experiment is conducted to analyze whether the power produced by the monocrystalline solar panel is in proportion with the energy pattern in the visible spectrum or not. A pictorial representation of visible spectrum is shown in the Fig. 2.

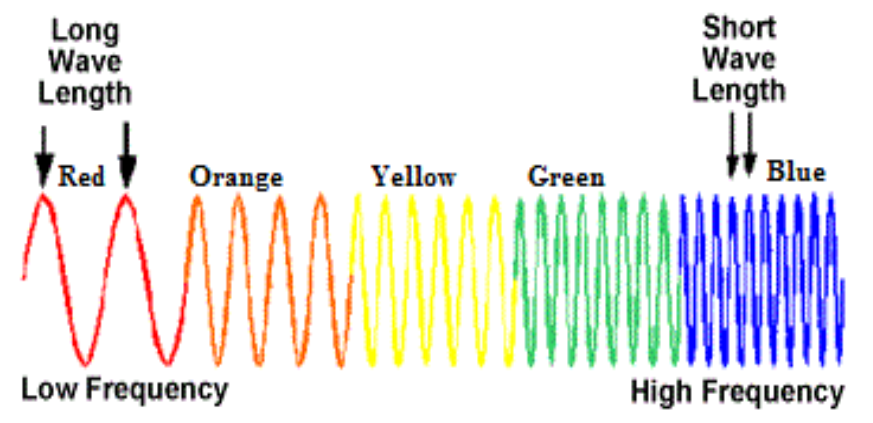

Low Energy

High Energy

Fig. 2: Representation of Visible Spectrum

According to electromagnetic spectrum the available energy associated with each wave decreases with increase in wavelength. So as per the theory violet should have maximum energy and energy should decrease gradually throughout the visible spectrum, from violet to red. Wavelength based experiment was conducted on the solar panel by illuminating it with lights of different wavelengths and measuring the response. The second experiment, the time based experiment is conducted to analyze the stability of current and voltage output from the solar panel. The solar panel is illuminated with wavelengths from violet to red for 20 minutes. The current and voltage developed are measured every 5 minutes. The third experiment is the irradiance based experiment. This experiment is conducted to measure the first response characteristics of the monocrystalline solar panel. The solar panel is illuminated by different levels of irradiation for each wavelength namely violet, blue, green, yellow and red. The momentary response of solar panel to different wavelengths is noted down.

\section{RESULTS AND DISCUSSION}

\section{A. Experiment Based on Wavelength on 0.18w Panel}

The experimental setup is the same as in Fig. 1. The LED flood light used in the experiment is capable of producing lights of 15 different wavelengths. Each of these lights are illuminated upon the small test solar panel. The Open circuit voltage, $\mathrm{V}_{\mathrm{oc}}$ and the short circuit current, $\mathrm{I}_{\mathrm{sc}}$ are noted down and tabulated as shown in Table I.

Table 1: Observed Values of Current and Voltage and Calculated Values of Power Developed on the Small Solar Panel in Wavelength Based Test

\begin{tabular}{|l|l|l|l|l|}
\hline $\begin{array}{l}\text { S1. } \\
\text { No. }\end{array}$ & LED colour & $V_{o c}(\mathrm{~V})$ & $I_{\mathrm{sc}}(\mathrm{mA})$ & $\mathrm{P}(\mathrm{mW})$ \\
\hline 1 & Violet $(380 \mathrm{~nm})$ & 1.86 & 3.62 & 6.733 \\
\hline 2 & Dark magenta & 1.85 & 3.45 & 6.383 \\
\hline 3 & Indigo $(450 \mathrm{~nm})$ & 1.85 & 3.34 & 6.179 \\
\hline 4 & Dark blue & 1.84 & 3.23 & 5.943 \\
\hline 5 & Blue $(475 \mathrm{~nm})$ & 1.84 & 3.13 & 5.759 \\
\hline 6 & Egyptian blue & 1.82 & 1.93 & 3.513 \\
\hline 7 & Spanish blue & 1.81 & 1.82 & 3.294 \\
\hline 8 & Fern green & 1.81 & 1.7 & 3.077 \\
\hline 9 & Chartreuse & 1.81 & 1.58 & 2.860 \\
\hline 10 & Green $(510 \mathrm{~nm})$ & 1.8 & 1.38 & 2.484 \\
\hline 11 & Yellow $(570 \mathrm{~nm})$ & 1.84 & 2.83 & 5.207 \\
\hline 12 & Amber & 1.85 & 2.9 & 5.365 \\
\hline 13 & Coral & 1.85 & 3.01 & 5.569 \\
\hline 14 & Orange $(600 \mathrm{~nm})$ & 1.85 & 3.15 & 5.828 \\
\hline 15 & Red $(650 \mathrm{~nm})$ & 1.86 & 3.51 & 6.529 \\
\hline
\end{tabular}

On experimentation with monocrystalline solar panel, it became evident that the power produced with each visible wavelength on solar panel is not in concurrence with the energy pattern in visible region of electromagnetic spectrum. The variation in power obtained with varying wavelengths is plotted as a graph as shown in Fig. 3.

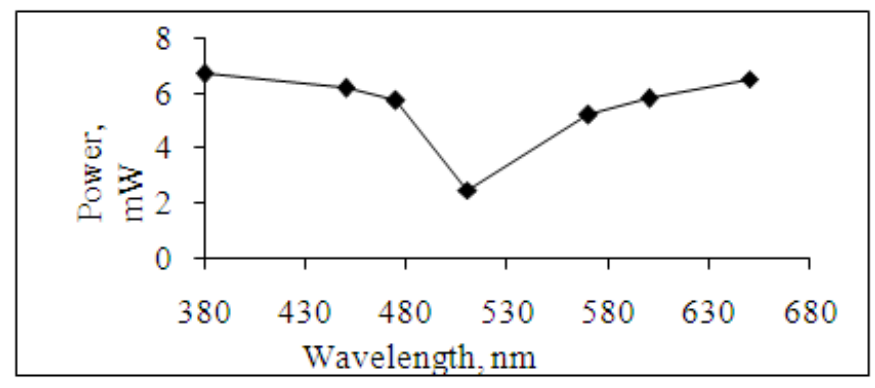

Fig. 3: Variation of Power Produced on the Small 0.18W solar Panel Illuminated by LEDs.

The theory of linear decrease of energy of a monochromatic light in the visible spectrum from violet to red doesn't hold well in case of monochromatic LED wavelengths. According to visible spectrum, violet has the maximum energy and the energy decreases gradually from 
violet to red. But the solar panel produced almost the same amount of energy from violet and red. Green produced the least energy for both $0.18 \mathrm{~W}$. The wavelength-power curve assumes a $\mathrm{V}$ shape.

\section{B. Experiment Based on Time on 0.18w Solar Panel}

The Open circuit voltage and short circuit current noted at every 5 minutes for 20 minutes with lights of wavelength violet, blue, green, yellow, orange and red and the values are tabulated. Table 2 shows the consolidated open circuit voltage values and short circuit current values. During the experiment, slight fluctuations in produced current and voltage has been observed.

Table 2: Observed Values of Current and Voltage with Time for Various LED Light Wavelengths on 0.18W Panel

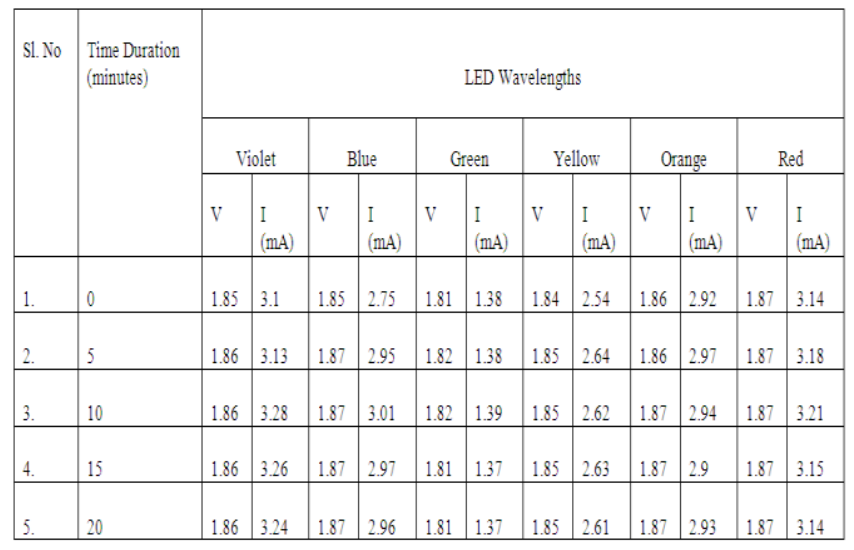

The consolidated values of current and voltage for each wavelength are depicted as graphs in Fig. 4 and Fig. 5

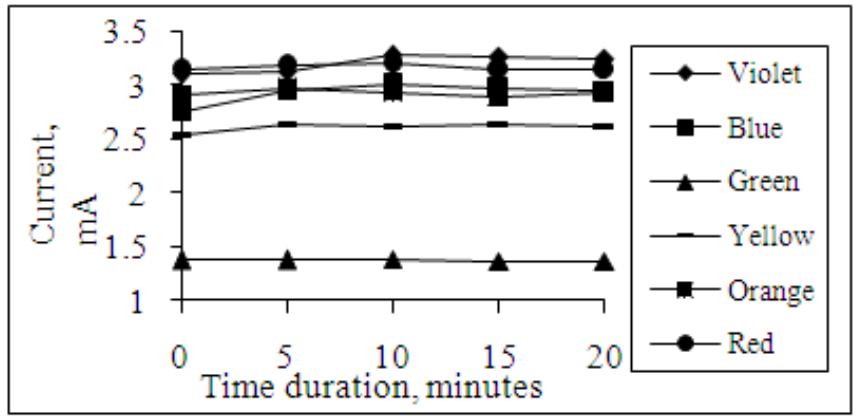

Fig. 4: Variation of Output Current with time on the Small 0.18W Solar Panel

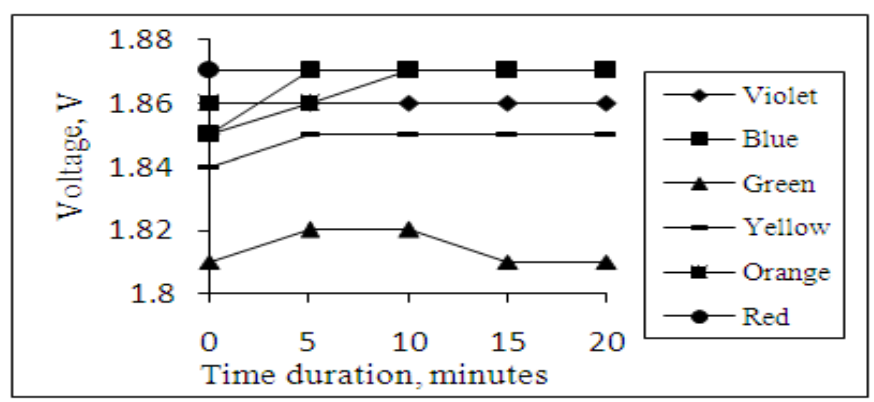

Fig. 5: Variation of Output Voltage with Time on the small 0.18W Solar Panel
During time based test, the LED illumination didn't produce much heat on solar panel. Red wavelength produced constant voltage throughout the experiment while green wavelength produced constant current throughout the experiment. The constancy of these two factors (current, voltage) is important in solar panel testing. These two wavelengths (green, red) may be developed for a better solar simulator than halogen solar simulators.

\section{Irradiance Based Test on 0.18W Solar Panel}

The values obtained from irradiance level based experiment are tabulated in Table. 3. Graphs are plotted for each wavelength as shown in Fig. 6. Red wavelength Red wavelength produced constant voltage while green wavelength produced constant current throughout the experiment. Red wavelength outperformed violet in terms of power produced in this test. Blue was the most efficient in terms of power to irradiance ratio. The $475 \mathrm{~nm}$ wave produced a power of 4.9 $\mathrm{mW}$ at a low irradiance value of $92 \mathrm{~W} / \mathrm{m}^{2}$. In irradiance based test on the solar panel, green and yellow wavelengths showed most linear relationship between irradiance and power.

Table 3: Observed values of Current and Voltage with Irradiance for Various LED Light Wavelengths

\begin{tabular}{|c|c|c|c|c|c|c|c|c|c|c|c|c|c|c|c|}
\hline \multirow{3}{*}{$\begin{array}{l}\text { Sl. } \\
\text { No }\end{array}$} & \multicolumn{15}{|c|}{ LED Light Wavelengths } \\
\hline & \multicolumn{3}{|c|}{ Violet } & \multicolumn{3}{|c|}{ Blue } & \multicolumn{3}{|c|}{ Green } & \multicolumn{3}{|c|}{ Yellow } & \multicolumn{3}{|c|}{ Red } \\
\hline & $\begin{array}{c}\mathrm{G} \\
\mathrm{W} / \mathrm{m}^{2}\end{array}$ & V & $\begin{array}{c}\mathrm{I} \\
\mathrm{mA} \\
\end{array}$ & $\begin{array}{c}\mathrm{G} \\
\mathrm{W} / \mathrm{m}^{2}\end{array}$ & V & $\begin{array}{c}\mathrm{I} \\
\mathrm{mA} \\
\end{array}$ & \begin{tabular}{|c|}
$G$ \\
$W / m^{2}$ \\
\end{tabular} & V & $\begin{array}{c}\mathrm{I} \\
\mathrm{mA} \\
\end{array}$ & $\begin{array}{c}\mathrm{G} \\
\mathrm{W} / \mathrm{m}^{2}\end{array}$ & V & $\begin{array}{c}\mathrm{I} \\
\mathrm{mA}\end{array}$ & $\begin{array}{c}\mathrm{G} \\
\mathrm{W} / \mathrm{m}^{2}\end{array}$ & V & $\begin{array}{c}\mathrm{I} \\
\mathrm{mA}\end{array}$ \\
\hline 1. & 0 & 0 & 0 & 0 & 0 & 0 & 0 & 0 & 0 & 0 & 0 & 0 & 0 & 0 & 0 \\
\hline 2. & 71.7 & 0.4 & 1.4 & 21.9 & 0.37 & 0.64 & 12 & 0.36 & 0.31 & 63.2 & 0.4 & 1.07 & 50 & $\begin{array}{l}0.3 \\
9\end{array}$ & 0.84 \\
\hline 3. & 128.1 & \begin{tabular}{|l}
0.8 \\
8 \\
\end{tabular} & $\begin{array}{ll}2.6 \\
7 \\
\end{array}$ & 43.6 & 0.88 & 1.9 & 23.6 & 0.6 & 0.6 & 107.2 & 0.64 & 1.77 & 99.6 & $\begin{array}{l}0.6 \\
3 \\
\end{array}$ & 1.6 \\
\hline 4. & 144.5 & $\begin{array}{l}1.1 \\
1 \\
\end{array}$ & 2.8 & 65.6 & 1.32 & 2.39 & 35.3 & 0.84 & 0.89 & 111.4 & 0.86 & 1.86 & 155.2 & $\begin{array}{l}0.8 \\
8\end{array}$ & 2.33 \\
\hline 5. & 1566 & $\begin{array}{l}1.3 \\
2 \\
\end{array}$ & 2.9 & 80.9 & 1.54 & 2.49 & 41.6 & 1.06 & 1.01 & 119.2 & 1.08 & 2 & 183.1 & $\begin{array}{l}1.1 \\
1 \\
\end{array}$ & 2.84 \\
\hline 6. & 178.1 & $\begin{array}{l}1.5 \\
4 \\
\end{array}$ & $\begin{array}{l}2.9 \\
7 \\
\end{array}$ & 88.3 & 1.74 & 2.58 & 50.2 & 1.69 & 1.22 & 127.2 & 1.31 & 2.13 & 193.2 & $\begin{array}{l}1.3 \\
3 \\
\end{array}$ & 2.89 \\
\hline 7. & 186.8 & \begin{tabular}{|l}
18 \\
7 \\
\end{tabular} & $\begin{array}{l}3.0 \\
4 \\
\end{array}$ & 92.8 & 1.86 & 2.65 & 52.1 & 1.81 & 1.29 & 145.8 & 1.86 & 2.55 & 198 & $\begin{array}{l}1.8 \\
7 \\
\end{array}$ & 3.11 \\
\hline
\end{tabular}
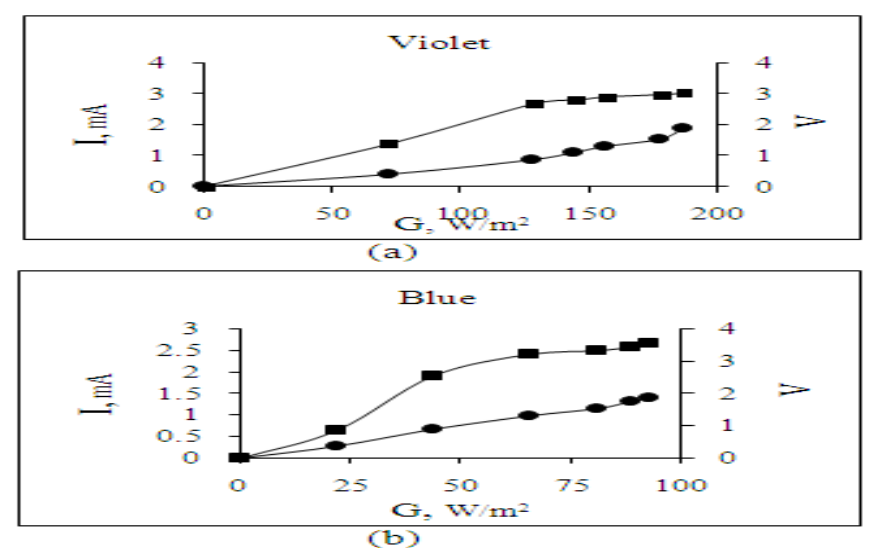
(c)

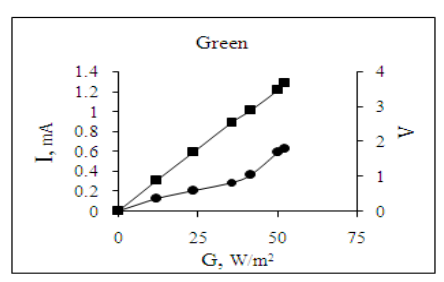

(d)
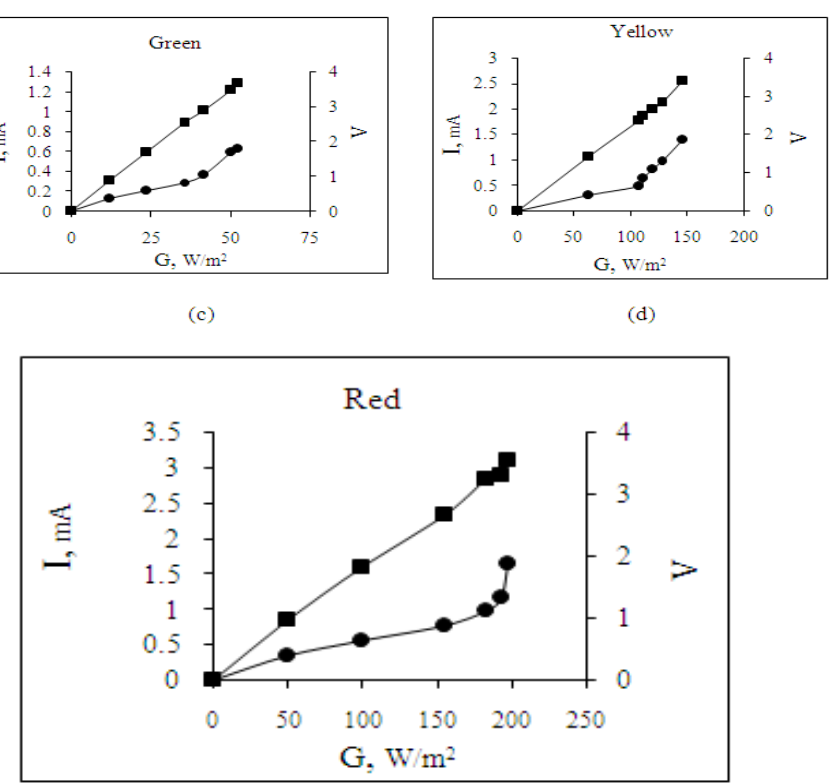

(e)

Fig. 6: Variation of Current and Voltage developed with Various Irradiation Levels on Monocrystalline Solar Panel Illuminated by a) violet LED b)blue LED c) green LED d) Yellow LED e) Red LED

The same experiments were repeated on a $20 \mathrm{~W}$ monocrystalline solar panel. This was done to understand whether the findings obtained in the small test panel concur when experimented on a commonly used solar panel. The values obtained and their analyses are detailed as follows:

\section{Experiment Based on Wavelength on 20W Solar Panel}

The obtained $\mathrm{I}_{\mathrm{sc}}$ and $\mathrm{V}_{\mathrm{oc}}$ and the calculated power are given in Table 4.

Table 4: Observed values of Current and Voltage and Calculated Values of Power developed on the 20W

Solar Panel in Wavelength Based Test

\begin{tabular}{|l|l|l|l|l|}
\hline $\begin{array}{l}\text { S1. } \\
\text { No. }\end{array}$ & LED colour & $I_{\text {sc }}(\mathrm{mA})$ & $\mathrm{V}_{\mathrm{oc}}(\mathrm{V})$ & $\mathrm{P}(\mathrm{mW})$ \\
\hline 1 & Violet $(380 \mathrm{~nm})$ & 1.85 & 3.62 & 6.733 \\
\hline 2 & Dark magenta & 1.84 & 3.45 & 6.383 \\
\hline 3 & Indigo $(450 \mathrm{~nm})$ & 1.81 & 3.34 & 6.179 \\
\hline 4 & Dark blue & 1.77 & 3.23 & 5.943 \\
\hline 5 & Blue $(475 \mathrm{~nm})$ & 1.69 & 3.13 & 5.759 \\
\hline 6 & Egyptian blue & 1 & 1.93 & 3.513 \\
\hline 7 & Spanish blue & 0.95 & 1.82 & 3.294 \\
\hline 8 & Fern green & 0.89 & 1.7 & 3.077 \\
\hline 9 & Chartreuse & 0.82 & 1.58 & 2.860 \\
\hline 10 & Green $(510 \mathrm{~nm})$ & 0.75 & 1.38 & 2.484 \\
\hline 11 & Yellow $(570 \mathrm{~nm})$ & 1.46 & 2.83 & 5.207 \\
\hline 12 & Amber & 1.5 & 2.9 & 5.365 \\
\hline 13 & Coral & 1.55 & 3.01 & 5.569 \\
\hline 14 & Orange $(600 \mathrm{~nm})$ & 1.65 & 3.15 & 5.828 \\
\hline 15 & Red $(650 \mathrm{~nm})$ & 1.83 & 3.51 & 6.529 \\
\hline
\end{tabular}

The results obtained here were similar to the wavelength based test done earlier on the small solar panel. The results are plotted as a graph in Fig. 7.

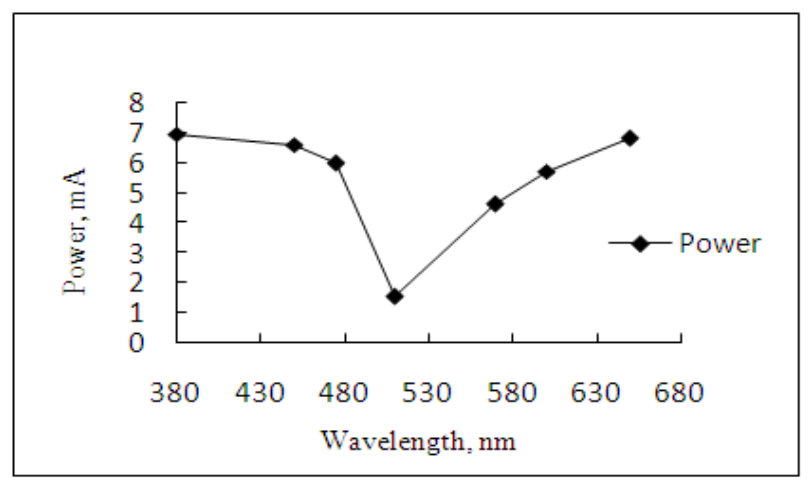

Fig. 7: Variation of Power produced on Monocrystalline Solar Panel Illuminated by LEDs

\section{E. Experiment Based on Time on 20W Solar Panel}

Just like experiment B, monochromatic lights of wavelength violet, blue, green, yellow, orange and red are illuminated upon the $20 \mathrm{~W}$ panel and the obtained $\mathrm{I}_{\mathrm{sc}}, \mathrm{V}_{\mathrm{oc}}$ values are tabulated in Table 5.

\section{Table 5: Observed values of Current and Voltage with time for various LED Light Wavelengths}

\begin{tabular}{|c|c|c|c|c|c|c|c|c|c|c|c|c|c|}
\hline \multirow{3}{*}{$\begin{array}{l}\text { S. } \\
\mathrm{N}_{0}\end{array}$} & \multirow{3}{*}{$\begin{array}{l}\text { Time } \\
\text { Duration } \\
\text { (mimutes) }\end{array}$} & \multicolumn{12}{|c|}{ LED Wardelengths } \\
\hline & & \multicolumn{2}{|l|}{ Violet } & \multicolumn{2}{|c|}{ Blue } & \multicolumn{2}{|c|}{ Green } & \multicolumn{2}{|c|}{ Yellow } & \multicolumn{2}{|c|}{ Orange } & \multicolumn{2}{|l|}{$\operatorname{Red}$} \\
\hline & & V & & V & I & V & I & V & $\begin{array}{l}\mathrm{I} \\
(\mathrm{mA})\end{array}$ & V & I $(\mathrm{mA})$ & V & $\begin{array}{l}\mathrm{I} \\
(\mathrm{mA})\end{array}$ \\
\hline 1. & 0 & 3.75 & 1.71 & 3.52 & 1.62 & 20. & 0.74 & 3.15 & 1.38 & 3.45 & 1.63 & 3.73 & \begin{tabular}{|l|}
1.74 \\
\end{tabular} \\
\hline 2. & 5 & 3.76 & 1.79 & 3.53 & 1.6 & 2.04 & 0.74 & 3.16 & 1.46 & 3.45 & 1.65 & 3.73 & 1.79 \\
\hline 3. & 10 & 3.76 & 1.85 & 3.53 & 1.69 & 2.04 & 0.75 & 3.16 & 1.42 & 3.46 & 1.63 & 3.73 & 1.83 \\
\hline 4. & 15 & 3.76 & 1.83 & 3.52 & 1.68 & 20. & 0.73 & 3.16 & 1.44 & 3.46 & 1.61 & 3.73 & 1.77 \\
\hline 5 & 20 & 3.76 & 1.81 & 3.53 & 1.66 & 20.3 & 0.73 & 3.16 & 1.43 & 3.46 & 1.63 & 3.73 & 1.74 \\
\hline
\end{tabular}

The consolidated values of current and voltage for each wavelength are depicted as graphs in Fig. 8 and Fig. 9.

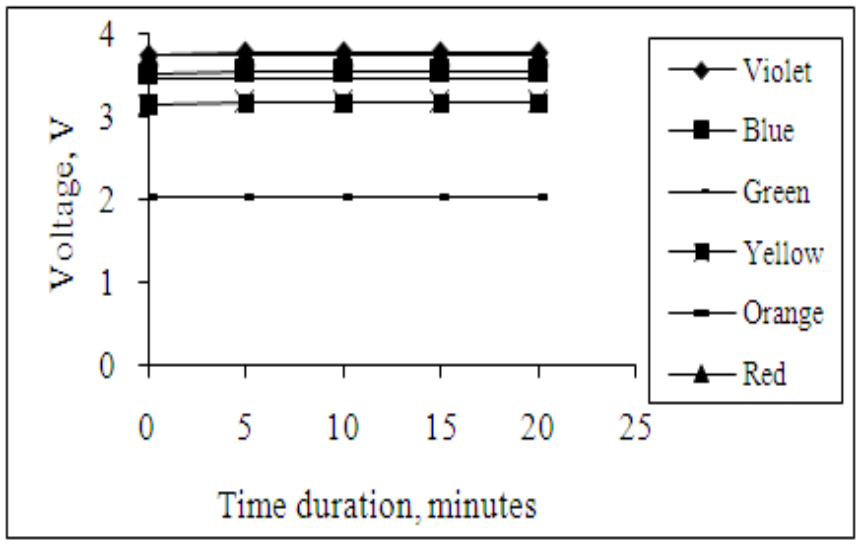

Fig. 8: Variation on Monocrystalline Solar Panel Illuminated by LEDs - Voltage with Time 


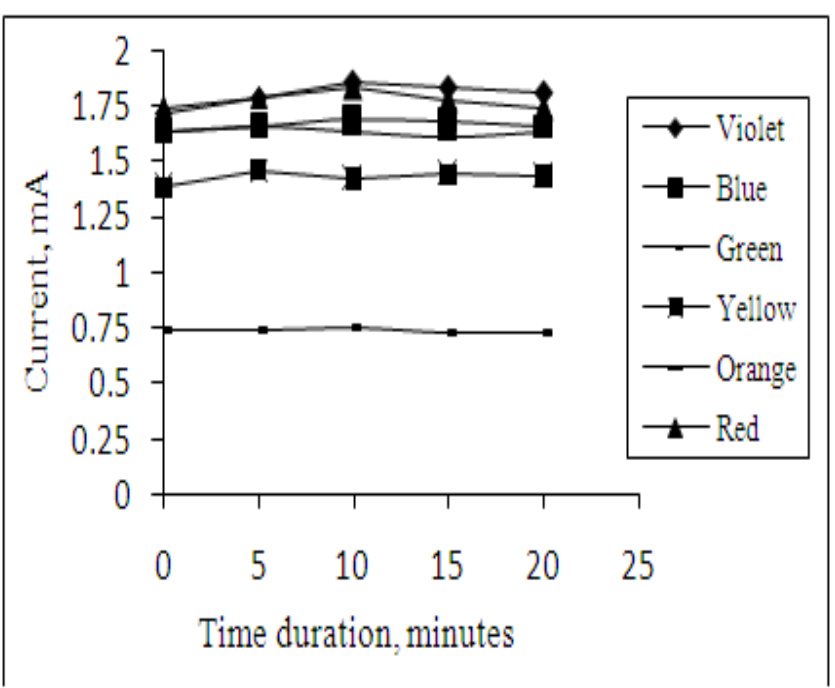

Fig. 9: Variation on Monocrystalline Solar Panel Illuminated by LEDs - Current with Time

Just like in the small test panel experiment, red wavelength produced constant voltage while green wavelength produced constant current throughout the experiment. But the constancy factor of red wavelength was not very predominant since the irradiance of the illuminated light lowered due to the increased distance of the light source from the panel.

\section{F. Irradiance Based Test}

The values obtained from irradiance level based experiment are tabulated in Table 6. Graphs are plotted for each wavelength as shown in Fig. 10. The pattern of values obtained was similar to that of irradiance test conducted on small test solar panel. Red wavelength outperformed violet in terms of power produced.

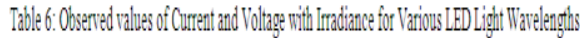

\begin{tabular}{|c|c|c|c|c|c|c|c|c|c|c|c|c|c|c|c|c|}
\hline & \multicolumn{16}{|c|}{ IED Light Waretengths } \\
\hline & \multicolumn{3}{|l|}{ Vidide } & \multicolumn{3}{|l|}{ Bule } & \multicolumn{4}{|c|}{ Green } & \multicolumn{3}{|c|}{ Yellor } & \multicolumn{3}{|l|}{ Red } \\
\hline & $\begin{array}{l}G \\
(\mathbb{N} \mathrm{m} \cdot)\end{array}$ & $\mathrm{Voc}_{0}$ & $\begin{array}{l}\text { Isc } \\
(\mathrm{mA})\end{array}$ & $\begin{array}{l}G \\
\mathbb{N} m:\end{array}$ & $V_{00}$ & Isc & & & $V_{0 c}$ & $\begin{array}{l}\text { Isc } \\
\text { (MA) }\end{array}$ & \begin{tabular}{|l}
$G$ \\
$(\mathbb{N}:)$
\end{tabular} & Voc & $\begin{array}{l}\mathrm{Iic} \\
(\mathrm{mA})\end{array}$ & $\begin{array}{l}G \\
\left(\mathbb{V}_{m}\right. \\
:)\end{array}$ & Voc & $\begin{array}{l}\text { Isc } \\
(\mathrm{mA})\end{array}$ \\
\hline 1. & 0 & 0 & 0 & 0 & 0 & 10 & 0 & & 0 & 0 & 0 & 0 & 0 & 0 & 0 & 0 \\
\hline 2. & 0.8 & 1.48 & 0.88 & 0.1 & $\begin{array}{l}1.0 \\
+ \\
\end{array}$ & 0.3 & 0 & & 0.99 & 0.19 & 0.8 & 1.27 & 0.66 & 0.7 & 1.2 & 0.48 \\
\hline 3. & 1.6 & 235 & 1.2. & 0.3 & 2.4 & 11. & 0 & & 0.92 & 0.35 & 1.5 & 222 & 1.11 & 1.5 & $\begin{array}{l}19 \\
3 \\
\end{array}$ & 0.99 \\
\hline t. & 2 & 3.09 & 172 & 0.4 & $\begin{array}{l}25 \\
2\end{array}$ & 12 & 0 & & 1.26 & 0.51 & 1.6 & 2.46 & 1.19 & 23 & 26 & 1.36 \\
\hline j. & 23 & 3.56 & 1.81 & 0.5 & 3 & 1.t. & 10 & & 1.96 & 0.59 & 19 & 289 & 1.33 & 29 & $\begin{array}{l}3.3 \\
7\end{array}$ & 173 \\
\hline 6. & 25 & 3.7 & 1.83 & 0.6 & 8 & 15 & 10 & 5 & 177 & 0.67 & 2 & 30.5 & 1.39 & 3 & $\begin{array}{l}3.5 \\
5 \\
\end{array}$ & 1.77 \\
\hline 7. & 2.6 & 3.76 & 1.88 & 0.7 & 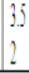 & 1.6 & & & 191 & 0.72 & 2.1 & 3.16 & 1.4 & 3.1 & $\begin{array}{l}3.7 \\
2\end{array}$ & 1.8 \\
\hline
\end{tabular}

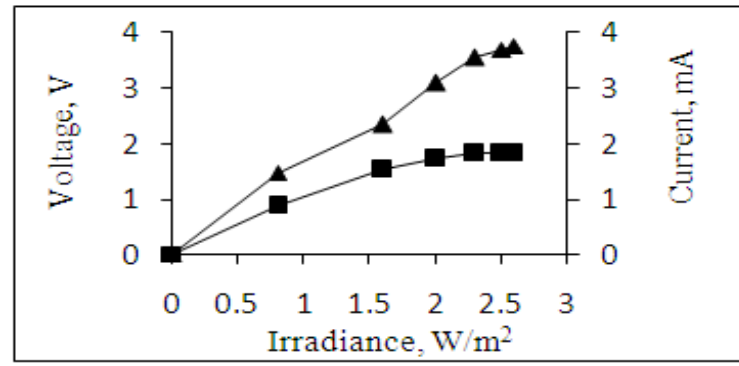

(a)

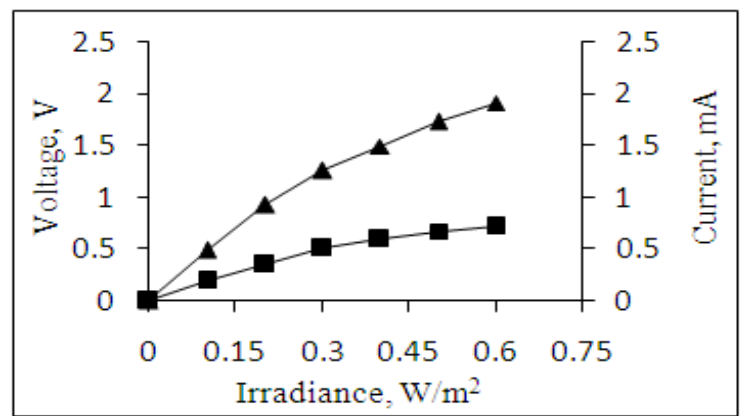

(b)

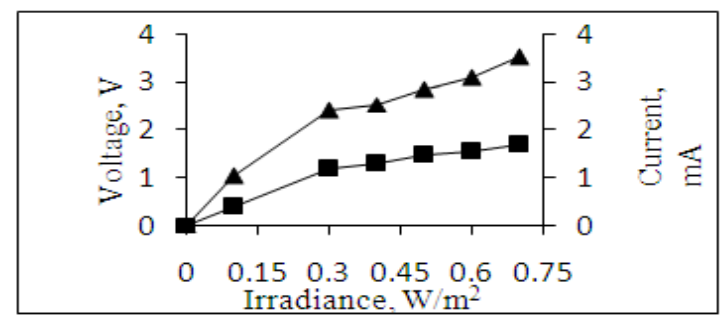

(c)

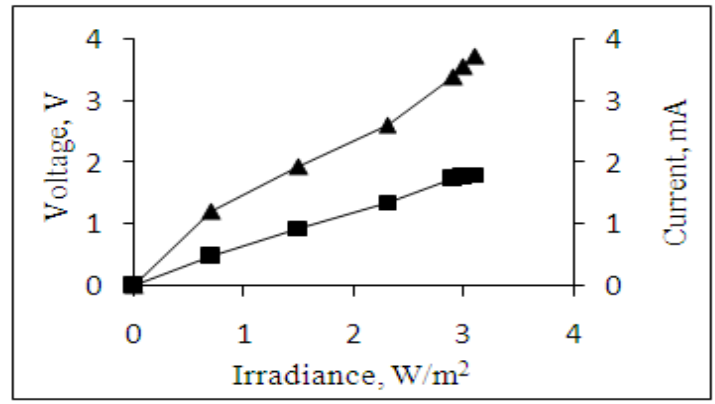

(d)

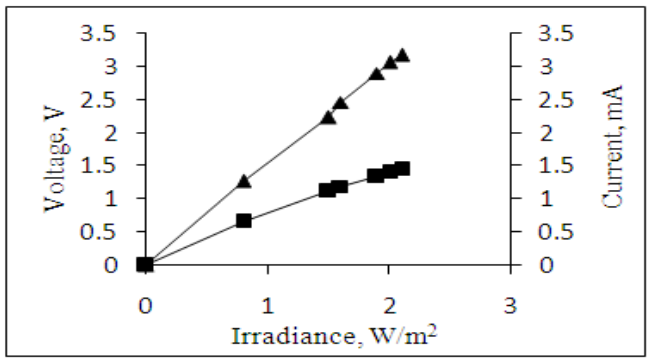

(e)

Fig. 10: Variation of Current and Voltage developed with various Irradiation Levels on Monocrystalline Solar Panel Illuminated by a) Violet LED b)Blue LED c) Green LED d) Yellow LED e) Red LED

G. Mathematical Conversion of $V_{o c}$ and $I_{s c}$ to STC

The standard Test Conditions (STC) for solar panels tested in laboratories are (1) irradiance intensity of $1000 \mathrm{~W} / \mathrm{m}^{2},(2)$ AM 1.5 solar reference spectrum, and cell module 
temperature of $25 \pm 2$ degrees $C$. Eventhough the tests in this experiment aren't conducted at laboratory conditions, the values obtained can be converted to STC by including some correction factors.

Using the procedure defined in IEC 891, the performance data will be converted to STC. The translated values of the performance parameters at STC are determined from these equations:

$$
\begin{gathered}
\operatorname{ISC}(S T C)=\frac{I S C\left(\frac{1000}{E}\right)}{[1+\alpha(T m-25)]} \\
\begin{aligned}
V o c(S T C)= \\
V o c /[1+\beta(T m-25)][1+\partial \times \ln (\mathrm{E})-\partial \\
\times \ln (1000)]
\end{aligned} \\
\text { Where } \begin{array}{l}
\mathrm{E}=\text { Obtained Irradiance } \\
\mathrm{Tm}=\text { Module Temperature } \\
\text { Temperature coefficient of } \mathrm{I}_{\mathrm{sc}}, \alpha=0 \\
\text { Temperature coefficient of } \mathrm{V}_{\mathrm{oc}}, \beta=0.06 \\
\text { Irradiance correction factor, } \delta=-0.004
\end{array} \\
\text { By using the equations provided above, the obtained } \\
\text { values of open circuit voltage and short circuit current are } \\
\text { converted to standard test conditions. The STC corrected } \\
\text { values of } \mathrm{I}_{\mathrm{sc}} \text { and } \mathrm{V}_{\mathrm{oc}} \text { for } 0.18 \mathrm{~W} \text { solar panel and 20W solar } \\
\text { panel are tabulated in table } 7 \text { and table } 8 \text { respectively. }
\end{gathered}
$$

\begin{tabular}{|c|c|c|c|c|c|}
\hline & & & & STC & STC \\
\hline $\begin{array}{c}\text { Wavelength } \\
(\mathrm{nm})\end{array}$ & $\begin{array}{c}\text { Irradiance } \\
\left(\mathrm{W} / \mathrm{m}^{2}\right)\end{array}$ & $\begin{array}{l}\text { Voc } \\
\text { (V) }\end{array}$ & $\begin{array}{c}\text { Isc } \\
(\mathrm{mA})\end{array}$ & $\begin{array}{l}\text { Voc } \\
\text { (V) }\end{array}$ & $\begin{array}{c}\text { Isc } \\
(\mathrm{mA})\end{array}$ \\
\hline $650(\mathrm{Red})$ & 3.1 & 3.72 & 1.8 & 3.636 & 580.645 \\
\hline $\begin{array}{l}600 \\
\text { (Orange) }\end{array}$ & 2.7 & 3.46 & 1.65 & 3.380 & 611.111 \\
\hline $\begin{array}{l}570 \\
\text { (Yellow) }\end{array}$ & 2.1 & 3.16 & 1.44 & 3.084 & 685.714 \\
\hline 510 (Green) & 0.6 & 1.91 & 0.72 & 1.855 & 1200.000 \\
\hline 475 (Blue) & 0.7 & 3.52 & 1.68 & 3.421 & 2400.000 \\
\hline 380 (Violet) & 2.6 & 3.76 & 1.83 & 3.673 & 703.846 \\
\hline
\end{tabular}

Table 7: STC corrected $\mathrm{V}_{\mathrm{oc}}$ and $\mathrm{I}_{\mathrm{sc}}$ Values for $0.18 \mathrm{~W}$ Solar Panel

\begin{tabular}{|c|r|c|c|c|c|}
\hline \multirow{2}{*}{$\begin{array}{c}\text { Wavelength } \\
(\mathrm{nm})\end{array}$} & $\begin{array}{c}\text { Irradiance } \\
\left(\mathrm{W} / \mathrm{m}^{2}\right)\end{array}$ & $\begin{array}{c}\text { Voc } \\
(\mathrm{V})\end{array}$ & $\begin{array}{c}\text { Isc } \\
(\mathrm{mA})\end{array}$ & $\begin{array}{c}\text { Voc } \\
(\mathrm{V})\end{array}$ & $\begin{array}{c}\text { Isc } \\
(\mathrm{mA})\end{array}$ \\
\hline 650 (Red) & 198 & 1.87 & 3.11 & 1.858 & 15.707 \\
\hline 600 (Orange) & 162 & 1.85 & 2.92 & 1.837 & 18.025 \\
\hline 570 (Yellow) & 145.8 & 1.86 & 2.55 & 1.846 & 17.490 \\
\hline 510 (Green) & 52.1 & 1.81 & 1.29 & 1.789 & 24.760 \\
\hline 475 (Blue) & 92.8 & 1.86 & 2.65 & 1.842 & 28.556 \\
\hline 380 (Violet) & 186.8 & 1.87 & 3.04 & 1.858 & 16.274 \\
\hline
\end{tabular}

Table 8: STC Corrected $\mathrm{V}_{o c}$ and $\mathrm{I}_{5 \mathrm{c}}$ Values for 20W Solar Panel

\section{FUTURE ENHANCEMENT}

In future we plan to conduct more tests using the experimentally found out optimum wavelengths for solar panel testing purposes, i.e., Green and Red. More powerful LEDs of the above said colors will be used. The desired irradiance is of one sun intensity. We plan to find out cheaper methods for solar panel testing.

\section{REFERENCES}

[1] W. Shockley and H. J. Queisser, "Detailed balance limit of efficiency of p-n junction solar cells", Journal of Applied Physics, Vol. 32, Issue 3, pp. 510-519, 1961.

[2] S. Hegedus, "Current-voltage analysis of a-Si and a-SiGe solar cells including voltage-dependent photocurrent collection", Progress in Photovoltaics: Research and Applications, Vol. 5, Issue 3, pp. 151-168, 1997.

[3] J. Merten and J. Andreu, "Clear separation of seasonal effects on the performance of amorphous silicon solar moduled by outdoor I/Vmeasurements", Solar Energy Materials and Solar Cells, Vol. 52, Issue 1, pp. 11-25, 1998.

[4] M. Burgelman and A. Niemegeers," Influence of illumination conditions on the design of thin-film modules", Solar Energy Materials and Solar Cells, Vol. 57, Issue 1, pp. 85-95, 22 February 1999.

[5] J. A. del Cueto, "Method for analyzing series resistance and diode quality factors from field data of photovoltaic modules", Solar Energy Materials and Solar Cells, Vol. 55, Issue 3, pp. 291-297, 1998.

[6] J. A. del Cueto, "Method for analyzing series resistance and diode quality factors from field data part II: applications to crystalline silicon", Solar Energy Materials and Solar Cells, Vol. 59, Issue 4, pp. 393-405, 1999.

[7] J. F. Randall and J. Jacot, "Is AM 1.5 applicable in practice? Modelling eight photovoltaic materials with respect to light intensity and two spectra", Renewable Energy, Vol. 28, Issue 12, pp. 1851-1864, 2003.

[8] A. Virtuani, E. Lotter, M. Powalla, "Performance of $\mathrm{Cu}(\mathrm{In}, \mathrm{Ga}) \mathrm{Se}_{2}$ solar cells under low irradiance", Thin Solid Films, Vol. 431-432, pp. 443447, 2003.

[9] L. Stamenic, E. Smiley, K. Karim, "Low light conditions modeling for building integrated photovoltaic (BIPV) systems", Solar Energy, Vol. 77, Issue 1, pp. 37-45, 2004.

[10] R. P. Kenny, E.D. Dunlop, H.A. Ossenbrink, H. Mullejans, "A practical method for the energy rating of c-Si photovoltaic modules based on standards tests", Progress in Photovoltaics: Research and Applications, Vol. 14, Issue 2, pp. 155-166, 2006.

[11] S. Hegedus, D. Desai, C. Thompson, "Voltage dependent photocurrent collection in CdTe/CdS solar cells", Progress in Photovoltaics: Research and Applications, Vol. 15, Issue 7, pp. 587-602, 2007.

[12] M. Topic, K. Brecl, J. Sites, "Effective efficiency of PV modules under field conditions", Progress in Photovoltaics: Research and Applications, Vol. 15, Issue 1, pp. 19-26, 2007.

[13] F. Nieuwenhout, N. vanderBorg, W. G. vanSark, W. C. Turkenburg, "A new method for estimating insolation based on PV-module currents in a cluster of stand-alone solar systems", Progress in Photovoltaics: Research and Applications, Vol. 15, Issue 5, pp. 387-404, 2007.

[14] S. Kohraku and K. Kurokawa, "New method for solar cell measurement by LED solar simulator", 3rd World conference on photovoltaic energy conversion, Vol. 2, pp. 1977-80, 2003.

[15] S. Kohraku and K. Kurokawa, "A fundamental experiment for discretewavelength LED solar simulator", Solar Energy Materials \& Solar Cells, Vol. 90, Issues 18-19, 3364-3370, 2006.

[16] R. Grischke et. al, "LED flasher arrays (LFA) for an improved quality control in solar cell production lines", 19th European Photovoltaic Solar Energy Conference, vol. 2, pp. 2519-94, 2004.

[17] J. Koyanagi and K. Kurokawa, "A fundamental experiment of solar cell's I-V characteristics measurement using LED solar simulator", Renewable Energy Proceedings, pp. 270-3, 2006.

[18] Y. Tsuno, K. Kamisako, K. Kurokawa, "New generation of PV module rating by LED solar simulator - a noval approach and its capabilities", Photovoltaic Specialists Conference, 2008.

[19] Martin Bliss, Thomas R Betts, Ralph Gottschalg, "An LED-based photovoltaic measurement system with variable spectrum and flash 
speed”, Solar Energy Materials and Solar Cells, Vol. 93, issue 6, pp. 825-830, 2009.

[20] Frederik C. Krebs, O. Kristian, Sylvester-Hvid and Mikkel Jorgensen, "A self-calibrating led-based solar test platform", Progress in Photovoltaics: Research and Applications, Vol 19, Issue 1, pp. 97-112, January 2011.

[21] A.M. Bazzi, Z. Klein, M. Sweeney et. al, "Solid-state light simulator with current-mode control", Applied Power Electronics Conference and Exposition (APEC), pp. 2047 - 2053, 2011.

[22] B. H. Hamadani, K. Chua et. al., "Towards realization of a large-area light-emitting diode-based solar simulator", Progress in Photovoltaics: Research and Applications, Vol. 21, Issue 4, pp. 779-789, June 2013.

[23] Furkan Dincer and Mehmet Emin Meral, "Critical Factors that Affecting Efficiency of Solar Cells", Smart Grid and Renewable Energy, pp. 47$50,2010$.

[24] IEC, IEC 891, "Procedures for temperature and irradiance corrections to measured I-V corrections of crystalline silicon photovoltaic devices", 1987. 